\title{
Germination, Morphological and Physiological Evaluation of Seedlings Pretreated with Colchicine in Soybean (Glycine max L)
}

\section{Phetole MANGENA}

Department of Biodiversity, School of Molecular and Life Sciences, Faculty of Science and Agriculture, University of Limpopo, Private Bag X1106, Sovenga 0727, Republic of South Africa

(Corresponding author's e-mail: phetole.mangena@ul.ac.za, mangena.phetole@gmail.com)

Received: 5 February 2020, Revised: 6 July 2021, Accepted: 13 July 2021

\begin{abstract}
Wider genetic diversity has the potential to improve crop productivity of soybean, especially under environmental stress conditions. The pre-treatment of soybean seeds with antimitotic agents to establish improved genetic pool may also contribute to the enhancement of germination, seedling development, morpho-physiological growth and yield. In this study, 2 soybean genotypes viz. TGx1835-10E and Dundee were imbibed in solutions containing different amounts of colchicine $(0.0,0.1,0.5$ and $1 \%)$ to evaluate the variations in germination, morphometric and physiological parameters. The seeds were imbibed for the period of 12 and $24 \mathrm{~h}$ before sowing for germination in plastic pots containing moistened sterile vermiculite. The variance components expressed as means, and mean percentage of total variations showed that colchicine concentration and imbibitional duration were the most important sources of variation for all traits, followed by the genotypes. Significant responses were detected for various germination parameters, seedling morphology and physiological contents such as; chlorophyll content, total phenolics, flavonoids as well as total protein and DNA content in the 2 genotypes used.
\end{abstract}

Keywords: Colchicine, Germination, Growth, Morpho-physiological parameters, Soybean

\section{Introduction}

Glycine max (L.) Merr. (Fabaceae) is a valuable leguminous pulse crop, widely known as soybean. This crop contains larger amounts of carbohydrates, proteins, unsaturated fats, essential oils, vitamins and other compounds that have health promoting effects [1]. However, soybean has a narrow genetic base, resulting in greater difficulties in developing new and improved crop varieties conferring tolerance in the various biotic and abiotic stress factors. Thus, plant breeders continue to optimise the available genetic manipulation techniques to introduce stress resistance genes from various sources into this crop, including other valuable legume crops. Some of the methods used for this purpose includes hybridization, genetic engineering and chemically induced mutagenesis. Over the years, research also focused on the use of colchicine, as a potential antimitotic mutagenic agent that prevent microtubules' function in chromosome separation [2]. Colchicine as one of mutagenic agent specifically interferes with the structure and orientation of mitotic and spindle fibres. Such effects cause subsequent increases in the growth characteristics such as sizes of leaves, fruits and seeds among plants successfully pre-treated with this chemical. This kind of genetic modifications have long gained popularity in many breeding systems. The approach still presents a viable alternative especially to genetic engineering, because it has received considerable attention to consumers and researchers, since concerns of genetic instability and possible carcinogenic activities are highly minimised.

In recent years, colchicine was widely used to derive many varieties of food and ornamental crops including legumes like soybean and cowpea [3]. Both in vitro and in vivo protocols were tested, practically obtaining new traits, creating genetic variability and supplementing conventional breeding in 
combating stress. As reported by Essel et al. [3], colchicine is the most preferred mutagenic agent because it is less fatal in plant cells compared to animal tissues, and it efficiently resulted in larger number of fertile seeds, fruits and a more desired plant growths. The need to exploit this technique for combating climate change and food insecurity in developing countries should not be over looked. Seed germination, morphological and physiological analyses are pivotal in understanding the role and effects of colchicine on plant growth and development. Furthermore, investigations are necessary to elucidate the responses of different genotypes, especially in developing stress resistant varieties. The continued use of mutagenic agents to develop stress resistant crops is perhaps the most fundamental service to mankind and the increasing populations. For the above-mentioned reasons, studies investigating the potential influence of colchicine on growth factors such as germination, seedling development, secondary metabolites, chlorophylls, DNA and proteins remains a prerequisite. Therefore, this study made the attempt to evaluate the differences in the quantity of the above-mentioned parameters between 2 soybean cultivars (Dundee and TGx1835-10E) pre-treated with varying concentrations of colchicine for the period of 6,12 and $24 \mathrm{~h}$ of seed imbibition.

\section{Materials and methods}

\section{Chemicals and materials}

Soybean [Glycine max (L.) Merr.] seeds cv. Dundee and TGx1835-10E were obtained from the Department of Biodiversity (Botany) and multiplied by planting at Amaloba nursery at the University of Limpopo, from September 2018 to March 2019. Colchicine (AR) powder, Folin-Ciocalteau, gallic acid, quercetin and glucose standard were purchased from Prestige Laboratory Supplies (Republic of South Africa). Eppendorf centrifuge tubes, aluminium nitrate $\left(\mathrm{Al}\left(\mathrm{NO}_{3}\right)_{3}\right)$, sodium nitrate $\left(\mathrm{NaNO}_{3}\right)$, sodium hydroxide $(\mathrm{NaOH})$, sulphuric acid $\left(\mathrm{H}_{2} \mathrm{SO}_{4}\right)$, acetone, methanol and phenol solution were purchased from Rochelle Chemicals and Lab Equipment (RSA). Gallenkamp Orbital Shaker and JENWAY's UV/VIS Spectrophotometer were purchased from Lasec SA and International Laboratory Supplies Ltd.

\section{Pre-treatment and germination of seeds}

The seeds of soybean were evaluated for germination initially by surface disinfection using chlorine gas for $16 \mathrm{~h}$ as described by Mangena et al. [4]. After sterilisation the seeds were then pre-treated with different concentrations of colchicine by pre-soaking them for 6, 12 and $24 \mathrm{~h}$ as shown in Table 1. Colchicine pre-treated seeds were then sown in $30 \mathrm{~cm}$ plastic pots containing heat sterilised vermiculite, which is a hydrous phyllosilicate mineral, used as a growth medium due to its non-toxic effect, neutral $\mathrm{pH}$, air-moisture retention capacity and it is nutrient-free. Seed cultures were then incubated for 10 days in a growth room under controlled environmental conditions. The growth room was equipped with white florescence light LED lamps at $120-200 \mu \mathrm{molm}^{-2} \mathrm{~s}^{-1}$ light intensity, $24 \pm 2{ }^{\circ} \mathrm{C}$ and $16-\mathrm{h}$ photoperiod. Germination was considered as the emergence of the epicotyl and the parameters were assessed as indicated on Table 2. 
http://wjst.wu.ac.th

Table 1 Determination of the effect of colchicine and duration of exposure on seed germination and morpho-physiological parameters in soybean.

\begin{tabular}{cccc}
\hline $\begin{array}{c}\text { Soybean } \\
\text { Cultivar Name }\end{array}$ & $\begin{array}{c}\text { Seed } \\
\text { Treatment ID }\end{array}$ & $\begin{array}{c}\text { Colchicine Level } \\
\text { (\%) }\end{array}$ & $\begin{array}{c}\text { Period of } \\
\text { Imbibition (h) }\end{array}$ \\
\hline Dundee & A1 & 0.1 & 6 \\
TGx1835-10E & A2 & 0.1 & 6 \\
Dundee & A3 & 0.5 & 6 \\
TGx1835-10E & A4 & 0.5 & 6 \\
Dundee & A5 & 1.0 & 6 \\
TGx1835-10E & A6 & 1.0 & 6 \\
Dundee & B1 & 0.1 & 12 \\
TGx1835-10E & B2 & 0.1 & 12 \\
Dundee & B3 & 0.5 & 12 \\
TGx1835-10E & B4 & 0.5 & 12 \\
Dundee & B5 & 1.0 & 12 \\
TGx1835-10E & B6 & 1.0 & 12 \\
Dundee & C1 & 0.1 & 24 \\
TGx1835-10E & C2 & 0.1 & 24 \\
Dundee & C3 & 0.5 & 24 \\
TGx1835-10E & C4 & 0.5 & 24 \\
Dundee & C5 & 1.0 & 24 \\
TGx1835-10E & C6 & 1.0 & 24 \\
Dundee & CD & -- & -- \\
TGx1835-10E & C10E & -- & -- \\
\hline
\end{tabular}

Table 2 Description of formulae used to study germination and seedling parameters following in vivo pretreatment of seeds in various concentrations of colchicine.

\begin{tabular}{|c|c|c|c|c|}
\hline Parameter & Symbol and Unit & Equation & Description & Reference \\
\hline $\begin{array}{l}\text { Final } \\
\text { Germination } \\
\text { Percentage }\end{array}$ & FGP $(\%)$ & $\mathrm{FGP}=\frac{N G}{n} \times 100$ & $\begin{array}{l}N G \text { - total number of } \\
\text { germinated seeds; } n \text { - is the } \\
\text { total number of tested seeds. }\end{array}$ & ISTA [13] \\
\hline $\begin{array}{l}\text { Mean Daily } \\
\text { Germination }\end{array}$ & MDG & $M D G=\frac{N G}{t}$ & $\begin{array}{l}N G \text { - total number of } \\
\text { germinated seeds; } t \text { - total } \\
\text { number of days. }\end{array}$ & Czabator [14] \\
\hline $\begin{array}{l}\text { Mean } \\
\text { Germination } \\
\text { Time }\end{array}$ & MGT (days) & $M G T=\sum F * \frac{x}{\sum^{F}}$ & $F$ - seed germinated on day $X$. & Kader [15] \\
\hline $\begin{array}{l}\text { Germination } \\
\text { Speed }\end{array}$ & GS (\%/day) & $\begin{array}{c}G S= \\
N 1 / t 1+N 2 / t 1 \ldots\end{array}$ & $\begin{array}{l}N \text { - the number of germinated } \\
\text { seeds; } t \text { - is the number of } \\
\text { days. }\end{array}$ & Czabator [14] \\
\hline Peak Value & PV & $P V=\frac{H S G}{t}$ & $\begin{array}{l}H S G \text { - highest number of seeds } \\
\text { germination; } t \text { - number of } \\
\text { days. }\end{array}$ & $\begin{array}{c}\text { Czabator [14], } \\
\text { Kader [15] }\end{array}$ \\
\hline
\end{tabular}


http://wjst.wu.ac.th

\begin{tabular}{|c|c|c|c|c|}
\hline Parameter & Symbol and Unit & Equation & Description & Reference \\
\hline $\begin{array}{l}\text { Germination } \\
\text { Value }\end{array}$ & GV & $G V=P V \times M D G$ & $\begin{array}{l}P V \text { - peak value; } M D G \text { - mean } \\
\text { daily germination, calculated } \\
\text { as indicated above. }\end{array}$ & Gairola et al. [16] \\
\hline $\begin{array}{l}\text { Germination } \\
\text { Index }\end{array}$ & GI & $G I=\sum(G T / T t)$ & $\begin{array}{l}G T \text { - total number of } \\
\text { germinated seeds; } T t \text { period } \\
\text { for the final and last } \\
\text { germination count. }\end{array}$ & Islam et al. [17] \\
\hline $\begin{array}{l}\text { Coefficient of } \\
\text { Velocity of } \\
\text { Germination }\end{array}$ & CVG & $\begin{array}{c}C V G=N 1+N 2+ \\
\cdots \frac{N x}{100} \times N 1 T 1+\cdots+ \\
N x T x=\end{array}$ & $\begin{array}{l}N \text { - is the number of seeds } \\
\text { germinated each day; } T \text { - } \\
\text { number of days from } \\
\text { corresponding to the } \\
\text { germinated seeds. }\end{array}$ & Kader [15] \\
\hline $\begin{array}{l}\text { Emergence } \\
\text { Rate }\end{array}$ & $\operatorname{ER}(\%)$ & $E R=\left(\frac{G T_{3}}{G T_{7}}\right) \times 100$ & $\begin{array}{l}G T_{3^{-}} \text {number of seeds } \\
\text { germinated } 3 \text { days after } \\
\text { sowing; } G T_{7^{-}} \text {number of seeds } \\
\text { germinated after } 7 \text { days of } \\
\text { sowing. }\end{array}$ & Islam et al. [17] \\
\hline $\begin{array}{l}\text { Seedling } \\
\text { Vigour Index }\end{array}$ & SVI & $S V I=\left(\frac{S L \times F G P}{100}\right)$ & $\begin{array}{l}S L \text { - seedling length }(\mathrm{mm}) \\
F G P \text {-final percentage } \\
\text { germination. }\end{array}$ & $\begin{array}{l}\text { Kader [15], } \\
\text { Islam et al. }[17]\end{array}$ \\
\hline
\end{tabular}

\section{Determination of phytochemicals and nucleic acids}

Plant chlorophyll pigments were isolated and determined using a procedure as described by Boyer [5] with modifications. Seedling samples were ground into fine powder in liquid nitrogen using a mortar and pestle. The ground tissues were immediately transferred into $50 \mathrm{~mL}$ centrifuge containers and stored at $-80{ }^{\circ} \mathrm{C}$ until use. Total chlorophyll content was then extracted from plant tissue homogenates of $0.1 \mathrm{~g}$ using $100 \%$ acetone, and then the acetone extract filtrates were quantified using a spectrophotometer at 661.6, 644.8 and $470 \mathrm{~nm}$. Average absorbance for each plant extract and levels of total chlorophyll content were calculated according to the equation on Table 3.

The concentration of phenolic contents were quantified based on a colorimetric assay method [6,7]. A $0.1 \mathrm{~g}$ of sample was extracted using $80 \%$ methanol and the mixture was centrifuged at 3,500 rpm for $10 \mathrm{~min}$. Plant extracts were mixed with Folin-Ciocalteau reagent and $1.5 \mathrm{~mL}$ of $20 \%$ sodium carbonate $\left(\mathrm{Na}_{2} \mathrm{CO}_{3}\right)$. The mixture was vortexed, incubated for $1 \mathrm{~h}$ and the absorbance measured at $765 \mathrm{~nm}$. The total phenolic content were then determined as gallic acid equivalents (mg GAE per gram of extract) using the formula indicated on Table 3.

Total flavonoid content was determined according to the procedure by Mrinova et al. [8] and Zhishen et al. [9]. The $0.1 \mathrm{~g}$ samples were weighted, and $15 \mathrm{~mL} 80 \%$ methanol was added for the extraction on an orbital shaker. The samples were centrifuged at 3,500 rpm for $10 \mathrm{~min}$. About $200-500$ $\mu \mathrm{L}$ of the supernatants were mixed with $2 \mathrm{~mL}$ distilled water and then further mixed with $1 \mathrm{~mL}$ of $5 \%$ sodium nitrate, vortexed and incubated for $5 \mathrm{~min}$ at room temperature. A $500 \mu \mathrm{L}$ of $10 \%$ aluminium nitrate solution was added to the mixture, and allowed to stand for $5 \mathrm{~min}$ before adding $1 \mathrm{~mL}$ of $1 \mathrm{M}$ $\mathrm{NaOH}$, and the absorbance read at $510 \mathrm{~nm}$. The absorbance of quercetin solutions used as standards were also measured at $510 \mathrm{~nm}$, and the flavonoid content was calculated as quercetin equivalents (mg Quer/g of extract) as shown on Table 3.

Total carbohydrate content were determined using phenol-sulphuric acid method as described by Masuko et al. [10] with slight modifications. Sample extracts were diluted to $2,000 \mu \mathrm{L}$ in $10 \mathrm{~mL}$ tubes and mixed with $1 \mathrm{~mL}$ of $5 \%$ phenol solution. A $2 \mathrm{~mL}$ of sulphuric acid was added to the mixture, vortexed and allowed to stand for $10 \mathrm{~min}$ at room temperature. The samples were then incubated in a 
water bath set at $30{ }^{\circ} \mathrm{C}$ for $30 \mathrm{~min}$. After the incubation, absorbances were measured at $490 \mathrm{~nm}$ using a spectrophotometer, and concentrations of total carbohydrates were calculated using the equation shown in Table 3.

Nucleic acid content were determined as described by Barbas et al. [11] and Bhusnure et al. [12]. Ground samples $(0.2 \mathrm{~g})$ were mixed with $8 \mathrm{~mL}$ CTAB (cetyl trimethylammonium bromide) extraction solution, mixed and incubated for $1 \mathrm{~h}$ with occasional agitation. An equal volume of acetone $(80 \%)$ was added, vortexed and centrifuged for $5 \mathrm{~min}$ at $10,000 \mathrm{rpm}$ at $4{ }^{\circ} \mathrm{C}$. The supernatant was collected and then washed several times with CTAB solution and acetone, followed by $30 \mathrm{~min}$ incubation in a water bath at 65 ${ }^{\circ} \mathrm{C}$. The mixture was then centrifuged for $5 \mathrm{~min}$ at 3,000 rpm, the supernatant was decanted, and the pellet resuspended in TE buffer (prepared by mixing $10 \mathrm{mM}$ Tris-Cl $\mathrm{pH}$ 8.0, 0.1 mM EDTA and $1 \mathrm{M} \mathrm{NaCl}$ ) to a 1 $\mathrm{mL}$ per gram of sample plant material. Sample extracts were then spectrophotometrically quantitated at $\mathrm{OD}_{260} / \mathrm{OD}_{280}$ ratio to determine the nucleic acid contents. The amounts of DNA and proteins were calculated using formula found in Table 3, with equivalent DNA ratio of 1.8 and protein ration of 2.0.

Table 3 Description of formulae used to determine total chlorophyll, phenolics, flavonoids, carbohydrates, DNA and protein content following in vivo pretreatment of seeds in various concentrations of colchicine.

\begin{tabular}{|c|c|c|c|c|}
\hline Parameter & $\begin{array}{c}\text { Symbol } \\
\text { and Unit }\end{array}$ & Equation & Description & Reference \\
\hline $\begin{array}{l}\text { Total } \\
\text { Chlorophyll }\end{array}$ & $\begin{array}{l}\text { Chla }+\mathrm{b} \\
(\mathrm{mg} / \mathrm{mL})\end{array}$ & $\begin{array}{c}\text { Chla }+b=7.05 \Delta \mathrm{A}_{661.6}+ \\
18.09 \Delta \mathrm{A}_{644.8}\end{array}$ & $\begin{array}{l}\text { Chla }+b \text {-concentration of } \\
\text { total chlorophyll in } m g / m L\end{array}$ & Boyer [5] \\
\hline $\begin{array}{l}\text { Total } \\
\text { Phenolics }\end{array}$ & $\begin{array}{l}\text { PT }(\mathrm{mg} \\
\text { GAE/g } \\
\text { extract }\end{array}$ & $P T=c \times V / m$ & $\begin{array}{l}c \text { - is the concentration of } \\
\text { gallic acid in } \mu g / m L, ~ V- \\
\text { volume of extract in } m L, m \text { - } \\
\text { is the weight }(g) \text { of extracts. }\end{array}$ & $\begin{array}{l}\text { Nikolova et al. } \\
{[18]}\end{array}$ \\
\hline $\begin{array}{l}\text { Total } \\
\text { Flavonoids }\end{array}$ & $\begin{array}{l}\text { TF (mg } \\
\text { Quer/g } \\
\text { extract }\end{array}$ & $T F=A s \times m c \times 10 / A c \times m s$ & $\begin{array}{l}A_{s^{-}} \text {absorbance of extract, } A_{c^{-}} \\
\text {standard quercetin } \\
\text { absorbance, } m_{s^{-}} \text {is the weight } \\
\text { of extract }(\mathrm{g}), \mathrm{mc}-\text { is the } \\
\text { weight of quercetin }(\mathrm{g})\end{array}$ & $\begin{array}{l}\text { Nikolova et al. } \\
{[18]}\end{array}$ \\
\hline $\begin{array}{l}\text { DNA and } \\
\text { Protein } \\
\text { content }\end{array}$ & $\begin{array}{l}\mathrm{NA} \\
(\mu \mathrm{g} / \mathrm{mL})\end{array}$ & $N A=\left(A_{260}-A_{280}\right) \times D$ & $\begin{array}{l}N A-\text { nucleic acids, } \mathrm{A}_{260^{-}} \text {is } \\
\text { the } N A \text { concentration } \\
\text { absorbance at } 260 \mathrm{~nm}, \mathrm{~A}_{280} \\
D \text { - is the dilution factor }(50 \\
\mu \mathrm{g} / \mathrm{mL}) . \quad \text { Proteins were } \\
\text { estimated from reading at } \\
\mathrm{A}_{280} .\end{array}$ & $\begin{array}{l}\text { Barbas et al. } \\
\text { [11], } \\
\text { Bhusnure et al. } \\
\text { [12] }\end{array}$ \\
\hline $\begin{array}{l}\text { Total } \\
\text { Carbohydrates }\end{array}$ & $\begin{array}{l}\mathrm{CHO} \\
(\mathrm{mg} / \mathrm{g})\end{array}$ & $C H O=\frac{C}{A c} \times A s \times D$ & $\begin{array}{l}C \text { - concentration of glucose, } \\
A c \text { - glucose absorbance, } A s- \\
\text { absorbance of the sample, } D \text { - } \\
\text { dilution factor. }\end{array}$ & Kafeel et al. [19] \\
\hline
\end{tabular}

\section{Growth conditions and statistical analysis}

Soybean seeds were surface sterilised using chlorine gas for $16 \mathrm{~h}$ and imbibed for respective periods (Table 1) at room temperature. All seed cultures were incubated in a growth room under $120-200 \mu \mathrm{molm}^{-2} \mathrm{~s}^{-1}$ light intensity, $24 \pm 2{ }^{\circ} \mathrm{C}, 50-60 \%$ humidity and 16-h photoperiod. Analysis of variance (ANOVA) was performed using version 25 to calculate individual means, and the samples' means were further compared using t-test at $5 \%$ confidence level. 


\section{Results and discussion}

\section{Effect of colchicine on germination}

The percentage germination of soybean seeds cv. TGx1835-10E and Dundee, pre-treated with varied concentrations of colchicine under 2 different durations were presented in Figure 1 and Table 4. Germination rates on pre-treated seeds ranged between 0 to $100 \%$, with cultivar Dundee achieving the highest percentage on seeds imbibed for $6 \mathrm{~h}$ with $0.5 \%$ colchicine (Figure 1). Germination further declined to $80,60,70,40$ and $20 \%$ for treatment A5, A1, A3, B2 and B4 for both 6 and $24 \mathrm{~h}$ of incubated soybean seeds. There was almost a complete polynomial decrease in percentage of germination with both the increase in colchicine concentration and period of incubation. As reported by Gairola et al. [16] germination remain quite complex to evaluate because several independent factors like temperature, light, oxygen and water affects each stage of the germination process in different ways. According to Dhakhanamoorthy et al. [21], if these factors are adequately available, each determines a fraction of the germinated seeds and the rate of the germination. Similarly, this study had clearly demonstrated the negative effects of colchicine on germination and seedling development. Percentage of germination was consistently high in the control (Dundee- $92 \%$ and TGx1835-10E- $90 \%$ ) compared to the colchicine pre-treated seeds, with A4, C3, C4, $\mathrm{C} 5$ and $\mathrm{C} 6$ recording $0 \%$ germination (Figure 1). The results also indicated that colchicine can be highly fatal to plant cells, as an effect already indicated in animal cells [3].

The reduction in other germination parameters were further observed with increasing seed imbibition period and colchicine concentration. Lower mean germination time (MGT) and mean daily germination (MDG) were recorded, which subsequently affected other germination parameters as indicated on Table 4. For example, treatment B4 had low MGT, which was further accompanied by decrease in GI and CVG when compared to the controls and seeds treated with minimum amounts of colchicine, at minimum imbibition period. Although, colchicine was reported to be well tolerated by plants and mostly resulting in improved morphological and reproductive characteristics [20]. Observations made in this study showed that pre-treatment of seeds with colchicine induced significant variations amongst treatment and the control. Similar findings were made by Essel et al. [3] in cowpea [Vigna unguiculata (L.) Walp] after pre-soaking dry and quiescent seeds in varying concentrations of colchicine $(0.05,0.10,0.15$ and $0.20 \mathrm{~g} / \mathrm{dl})$ for $3 \mathrm{~h}$. The findings made in this study also illustrated significant differences in means of recorded germination based on the genotype. Soybean cultivar Dundee (A1, A3, A5, B1, B3, B5 and C1) mostly recorded a high mean number of germination parameters as showed on Figure 1 and Table 4, compared to TGx1835-10E.

\section{Effect of colchicine on seedling phytochemicals and nucleic acid}

Colchicine has been reported to have caused inhibitory effects on seedling development leading to poor plant growth [21]. In this study, the reduction in germination percentage as a result of colchicine exposure and poor survival of germinated seeds led to a dramatic decrease in seedlings growth. It was observed that high amount of colchicine inhibited radicle and epicotyl emergence in seeds pre-treated with the substance at $0.5-1 \%$. Soybean seeds imbibed for germination on $1 \%$ colchicine showed poor growth and mass deaths of seedlings. Furthermore, there was significant variation among all treatments regarding the period of imbibition. It was observed that seedling formations was more successful in $\mathrm{C} 1$ and $\mathrm{C} 2$ incubated for $6 \mathrm{~h}$ compared to seeds pre-treated for more than this period. Pande and Khetmalas [22] also reported such growth inhibitory effects on Stevia rebaudiana using mutagenic sodium azide and colchicine at 0 to $0.250 \%$ for 12 and $24 \mathrm{~h}$ at room temperature. The reduction in germination rates with subsequent negative effects on seedling growth were also reported by Widoretno [23] in Pogostemon cablin Benth and Khalili et al. [24] in Gerbera jamesonii Bolus cv. Mini Red. The pre-treatment of seeds with colchicine also increased hypocotyl girth as reported by Essel et al. [3]. However, studies that used lesser amounts of colchicine for prolonged duration reported significantly varied contradictory results. Such reports include that of Udensi and Ontuni [25] which showed improved growth, especially under prolonged incubation periods for germination and seedling establishment.

The significant differences among the treatments were not only limited to germination and seedling morphology, but variations were also observed in the total content of chlorophyll, phenolics, flavonoids, 
carbohydrates and nucleic acids. The varied compositions of these phytochemicals were determined by decrease/increase in absorbance using spectrophotometric quantifications. Therefore, getting the systematic results of these phytochemicals in Dundee and TGx1835-10E soybean cultivars remain highly important for research and development of legumes against biotic and abiotic stresses. The results of the analysed samples and their activities were illustrated in Figure 2 and Table 5.

In terms of total chlorophyll content, almost all samples were varied and significant, except A6 (2.04 \pm 0.13$)$ and B3 (2.03 \pm 0.13$)$, as well as B4 (2.70 \pm 0.18$)$ and B6 (2.71 \pm 0.18$)$ giving similar mean readings as shown in Table 5. This was the case despite of the fact that these emanated from the different colchicine pre-treatments and imbibition periods. It can also be seen that the highest total chlorophyll content was observed in $\mathrm{C} 1(6.99 \pm 0.45)$ amongst the treatments, and the maximum in the controls $\mathrm{CD}(8.05 \pm 0.43)$ and C10E (9.68 \pm 0.35$)$. Results indicated that colchicine impacted negatively on chlorophyll content since the minimum was observed on pre-treated seeds and the maximum on the controls. These findings were in conflict with Amiri et al. [26] who reported that chlorophyll content in treatment $22.5 \mu \mathrm{M} / 48 \mathrm{~h}$ was greater than in the treatment $22.5 \mu \mathrm{M} / 24 \mathrm{~h}$ of colchicine. This further indicated that imbibition period can also have an impact on total chlorophyll content as well.

Based on Figure 2 results, the highest content of phenolics were obtained in C2 and B4, both treated with increasing amounts of colchicine for 6 and $12 \mathrm{~h}$. These were even higher than those obtained in the controls. Among all the treatments, the highest phenolic content was found in soybean seeds pre-treated with $0.5 \%$ colchicine B4 (56.67 mg GAE/g extract), followed by C2 (44, $85 \mathrm{mg} \mathrm{GAE} / \mathrm{g}$ extract), $44.03 \mathrm{mg}$ GAE/g extract), A5 (30.32 mg GAE/g extract) and A6 (28.47 mg GAE/g extract). Overall, phenolic contents were significantly higher in cultivar TGx1835-10E treatments than in Dundee, which demonstrated individual treatment achievement. The differences in phenolic content, however, were not found to be statistically significant for all the pre-treated seeds, especially between treatment A2 and A3 as well as B1 and B3. Such variations could be observed in a wide variety of plant species and organs, often influenced by growing conditions [27].

The total flavonoids content in different colchicine treatments are also shown in Figure 2 (E-H). Among colchicine pre-treated germinated seedlings, the highest amount of flavonoid content was observed in A1 (8.48 mg Quer/g extract), B3 (1.69 mg Quer/g extract) and C2 (1.319 mg Quer/g extract). Whereas in the controls, Dundee recorded the highest flavonoid content (5.15 mg Quer/g extract) than TGx1835-10E (1.05 mg Quer/g extract). As plants are potential sources of these phytochemicals [28], these results have also shown variations according to colchicine concentration and at a lesser extend according to cultivar differences.

The results regarding total sugar content of all the colchicine pre-treated seeds and the control is also presented in Table 5. Mean carbohydrates values ranged from 2.03 to $7.50 \mathrm{mg} / \mathrm{mL}$ in pre-treated seeds and 8.05 to $9.68 \mathrm{mg} / \mathrm{mL}$ in the control. Overall, total carbohydrate content lies between 2.03 to $9.68 \mathrm{mg} / \mathrm{mL}$ with a clear reduction based on colchicine level and imbibition period. The concentration of sugars obtained were negatively influenced by the poor growth responses of colchicine pre-treated seedlings. This has further affected the ability of the plant to produce starches and soluble sugars as a product of photosynthesis [19]. The concentration of plant nutrients/carbohydrates plays a key role in various metabolic activities of the plant that are essential in promoting seedling growth. Furthermore, the present research findings also indicated that, sufficient nucleic acids were also significant. Colchicine appeared slightly non-toxic to DNA and protein formation, except for A1 and C2 which recorded significantly lower amounts of $0.92 \mu \mathrm{g} / \mathrm{mL}$ and $0.29 \mu / \mathrm{mL}$ for DNA and Protein, respectively. The values also showed that the solutions of nucleic acids had less contaminations. Some of the reported contaminants may include phenolics and lipids [29]. Of all the treatments, B1 yielded a high amount of DNA than proteins, followed by A3 with high amounts of both DNA and proteins, followed by A5 which had a good quantity of both as indicated in Table 5. 


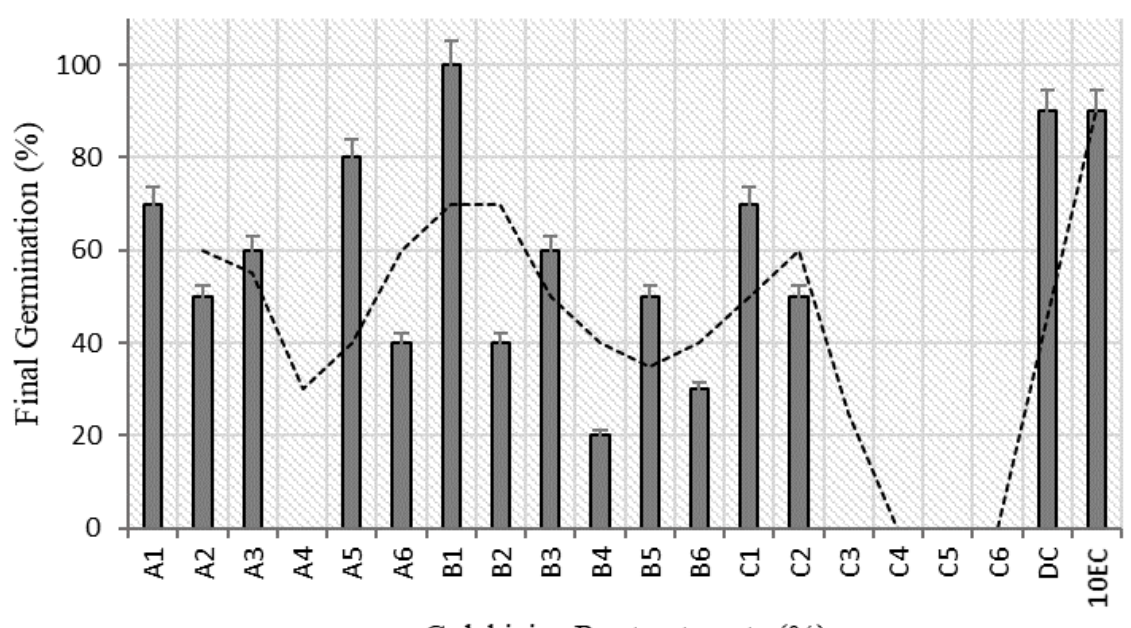

Colchicine Pre-treatments (\%)

Figure 1 Mean final germination percentage of soybean cv. Dundee and TGx1835-10E seeds pre-treated with different concentrations of colchicine under different periods of incubation in soybean. Values with similar letters are not significantly different at $0.05 p$-value using t-test.

Table 4 Mean comparison of germination parameters of soybeans cultivar Dundee and TGx1835-10E seeds pre-treated with varying concentration of colchicine.

\begin{tabular}{clllllll}
\hline Treatments & \multicolumn{1}{c}{ MGT } & \multicolumn{1}{c}{ MDG } & \multicolumn{1}{c}{ GS } & \multicolumn{1}{c}{ GI } & \multicolumn{1}{c}{ GV } & \multicolumn{1}{c}{ PV } & \multicolumn{1}{c}{ CVG } \\
\hline A1 & $2.19 \pm 0.13$ & $59.5 \pm 1.28^{*}$ & $5.95 \pm 1.28$ & $79.0 \pm 0.53$ & $5.95 \pm 1.29$ & $1.00 \pm 2.20^{*}$ & $175 \pm 0.81$ \\
A2 & $1.40 \pm 0.18$ & $35.6 \pm 0.70$ & $3.56 \pm 0.70$ & $46.0 \pm 0.31$ & $2.55 \pm 0.02$ & $0.70 \pm 1.30^{* * * *}$ & $111 \pm 0.67$ \\
A3 & $1.93 \pm 1.09$ & $60.3 \pm 1.73^{*}$ & $6.31 \pm 1.73^{*}$ & $81.0 \pm 0.55$ & $5.41 \pm 1.09$ & $0.90 \pm 2.10$ & $150 \pm 0.58$ \\
A4 & 0.00 & 0.00 & 0.00 & 0.0 & 0.00 & 0.00 & 0.00 \\
A5 & $2.46 \pm 1.41$ & $63.8 \pm 1.28$ & $6.38 \pm 1.28^{*}$ & $84.0 \pm 0.56$ & $7.29 \pm 1.92$ & $1.102 .40 \pm$ & $196 \pm 0.36$ \\
A6 & $1.20 \pm 0.70^{*}$ & $27.9 \pm 0.46$ & $2.79 \pm 0.46$ & $36.0 \pm 0.24$ & $1.59 \pm 0.39$ & $0.60 \pm 1.10^{* *}$ & $95 \pm 0.65$ \\
B1 & $3.40 \pm 1.84$ & $100 \pm 2.19$ & $11.10 \pm 2.19$ & $146.0 \pm 0.98$ & $15.85 \pm 0.55$ & $1.40 \pm 4.60$ & $276 \pm 0.51$ \\
B2 & $1.20 \pm 0.67 *$ & $32.5 \pm 0.38^{* *}$ & $3.25 \pm 0.38^{* *}$ & $43.0 \pm 0.29$ & $1.86 \pm 0.64$ & $0.60 \pm 1.50^{* *}$ & $97 \pm 0.67$ \\
B3 & $2.00 \pm 1.09$ & $55.6 \pm 0.60$ & $5.56 \pm 0.60$ & $75.0 \pm 0.49$ & $4.76 \pm 0.35$ & $0.90 \pm 2.70$ & $162 \pm 0.21 *$ \\
B4 & $0.70 \pm 0.36$ & $18.5 \pm 0.20$ & $1.85 \pm 0.20$ & $25.0 \pm 0.17$ & $0.53 \pm 0.74$ & $0.30 \pm 0.90$ & $54 \pm 0.70$ \\
B5 & $1.60 \pm 0.88^{* *}$ & $40.4 \pm 0.45$ & $4.21 \pm 0.45^{* * *}$ & $56.0 \pm 0.37$ & $3.01 \pm 0.39 *$ & $0.70 \pm 2.00^{* * * *}$ & $120 \pm 0.98$ \\
B6 & $1.07 \pm 0.58$ & $32.8 \pm 0.50 * *$ & $3.28 \pm 0.50^{* *}$ & $45.0 \pm 0.30$ & $1.41 \pm 0.83$ & $0.40 \pm 1.50$ & $87 \pm 0.70$ \\
C1 & $2.10 \pm 1.21$ & $53.2 \pm 1.03$ & $5.32 \pm 1.03$ & $69.0 \pm 0.46$ & $5.32 \pm 1.03$ & $1.00 \pm 2.00^{*}$ & $167 \pm 0.36 *$ \\
C2 & $1.60 \pm 0.92 * *$ & $42.1 \pm 0.86$ & $4.21 \pm 0.86^{* * *}$ & $59.0 \pm 0.37$ & $3.01 \pm 0.07 *$ & $0.70 \pm 1.60$ & $128 \pm 0.39$ \\
C3 & 0.00 & 0.00 & 0.00 & 0.0 & 0.00 & 0.00 & 0.00 \\
C4 & 0.00 & 0.00 & 0.00 & 0.0 & 0.00 & 0.00 & 0.00 \\
C5 & 0.00 & 0.00 & 0.00 & 0.0 & 0.00 & 0.00 & 0.00 \\
C6 & 0.00 & 0.00 & 0.00 & 0.0 & 0.00 & 0.00 & 0.00 \\
CD & $2.79 \pm 1.60$ & $76.0 \pm 1.64$ & $7.60 \pm 1.64$ & $101.0 \pm 0.68$ & $9.78 \pm 1.92$ & $1.30 \pm 2.80^{* * *}$ & $223 \pm 0.95$ \\
C10E & $2.60 \pm 1.50$ & $69.0 \pm 1.45$ & $6.90 \pm 1.45$ & $90.0 \pm 0.60$ & $8.88 \pm 0.39$ & $1.30 \pm 2.50^{* * *}$ & $207 \pm 0.94$ \\
\hline & & & & & & &
\end{tabular}

Values with asterisks $(*)$ are not significantly different at $0.05 p$-value using t-test. MGT= mean germination time; $\mathrm{MDG}=$ mean daily germination; $\mathrm{GS}=$ germination speed; $\mathrm{GI}=$ germination index; $\mathrm{GV}$ = germination value; $\mathrm{PV}=$ peak value $\mathrm{CVG}=$ coefficient of velocity of germination. 
http://wjst.wu.ac.th

Table 5 Mean comparison of total phytochemical and nucleic acid contents found in 7-day seedlings germinated from seeds pre-treated with varying concentration of colchicine in soybean cv. Dundee and TGx1835-10E.

\begin{tabular}{clllll}
\hline $\begin{array}{c}\text { Colchicine } \\
\text { Pre-treatments }\end{array}$ & $\begin{array}{c}\text { Total } \\
\text { Chlorophyll } \\
(\mathbf{m g} / \mathbf{m L})\end{array}$ & $\begin{array}{c}\text { Total } \\
\text { Carbohydrates } \\
(\mathbf{m g} / \mathbf{g} \mathbf{D W})\end{array}$ & $\begin{array}{c}\text { DNA } \\
(\boldsymbol{\mu g} / \mathbf{m L})\end{array}$ & $\begin{array}{c}\text { Proteins } \\
(\boldsymbol{\mu g} / \mathbf{m L})\end{array}$ & $\begin{array}{c}\text { DNA-Protein } \\
\text { Precipitation } \\
(\boldsymbol{\mu} / \mathbf{m L})\end{array}$ \\
\hline A1 & $5.74 \pm 0.38$ & $1.07 \pm 0.18^{*}$ & 0.920 & $1.377^{*}$ & 2.297 \\
A2 & $5.45 \pm 0.36$ & $0.93 \pm 0.15^{* *}$ & 2.511 & 1.196 & 3.707 \\
A3 & $3.41 \pm 0.23$ & $1.07 \pm 0.18^{*}$ & 2.914 & $1.383^{*}$ & 4.297 \\
A4 & 0.00 & 0.00 & 0.00 & 0.00 & 0.00 \\
A5 & $6.41 \pm 0.44$ & $0.70 \pm 0.12$ & $1.900^{* *}$ & 1.902 & $3.802^{*}$ \\
A6 & $2.04 \pm 0.13^{*}$ & $0.99 \pm 0.163^{* *}$ & 2.686 & 1.275 & 3.961 \\
B1 & $7.50 \pm 0.51$ & $0.80 \pm 0.13$ & 4.107 & 0.858 & 4.965 \\
B2 & $6.48 \pm 0.42$ & $1.18 \pm 0.19$ & 0.605 & 1.265 & 1.870 \\
B3 & $2.03 \pm 0.13^{*}$ & $1.55 \pm 0.26^{* * *}$ & $1.793^{*}$ & 1.656 & 3.449 \\
B4 & $2.70 \pm 0.17 * *$ & $1.51 \pm 0.25^{* * *}$ & $1.773^{*}$ & 1.616 & 3.389 \\
B5 & 0.00 & 0.00 & 0.00 & 0.00 & 0.00 \\
B6 & $2.71 \pm 0.18^{* *}$ & $1.52 \pm 0.19^{* * *}$ & 1.609 & 1.273 & 2.882 \\
C1 & $6.99 \pm 0.45$ & $1.19 \pm 0.17$ & $1.922^{* *}$ & 1.311 & 3.233 \\
C2 & $3.78 \pm 0.25$ & $0.98 \pm 0.16^{* *}$ & 1.854 & 0.295 & 2.149 \\
C3 & 0.00 & 0.00 & 0.00 & 0.00 & 0.00 \\
C4 & 0.00 & 0.00 & 0.00 & 0.00 & 0.00 \\
C5 & 0.00 & 0.00 & 0.00 & 0.00 & 0.00 \\
C6 & 0.00 & 0.00 & 0.00 & 0.00 & 0.00 \\
CD & $8.05 \pm 0.43$ & $0.84 \pm 0.14^{* * * *}$ & 2.746 & $1.082^{* *}$ & $3.828^{*}$ \\
C10E & $9.68 \pm 0.35$ & $0.80 \pm 0.13^{* * * *}$ & 2.664 & $1.085^{* *}$ & 3.749 \\
\hline & & & & & \\
\hline
\end{tabular}

Values with asterisks $\left({ }^{*}\right)$ within columns are not significantly different at $0.05 p$-value using t-test. DWdry weight of crushed sample extract. 
http://wjst.wu.ac.th

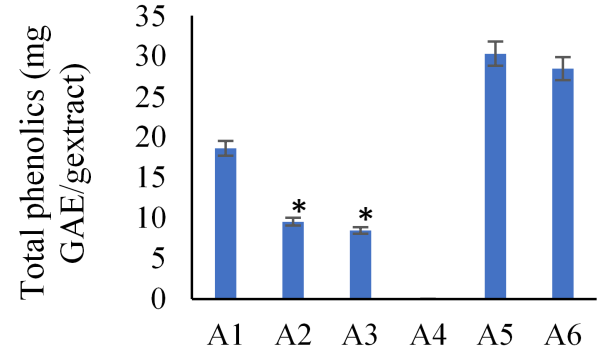

(A) Colchicine Pre-treatment

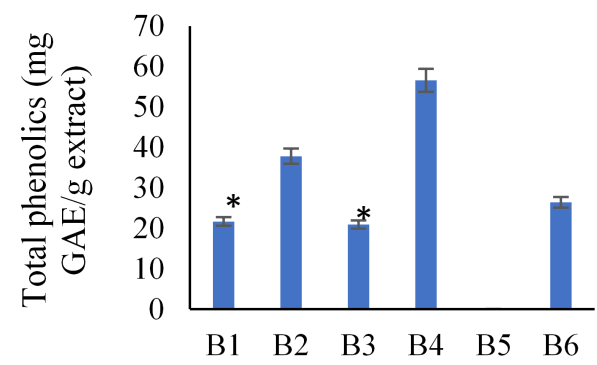

(B) Colchicine Pre-treatment

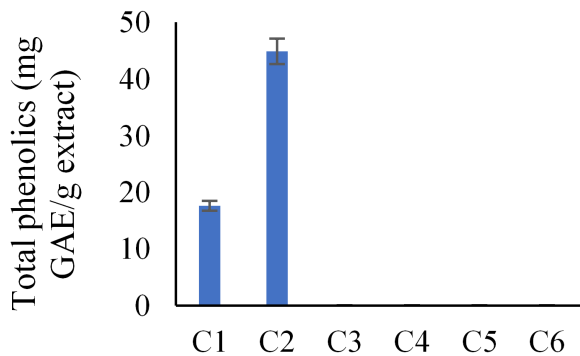

(C) Colchicine Pre-treatment

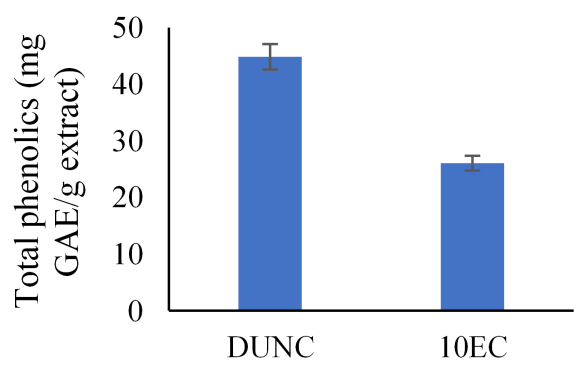

(D) Colchicine Pre-treatment

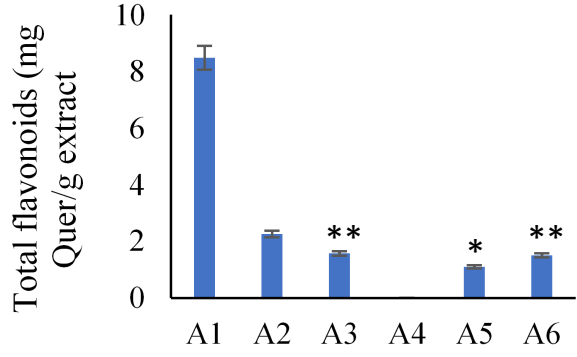

(E) Colchicine Pre-treatment

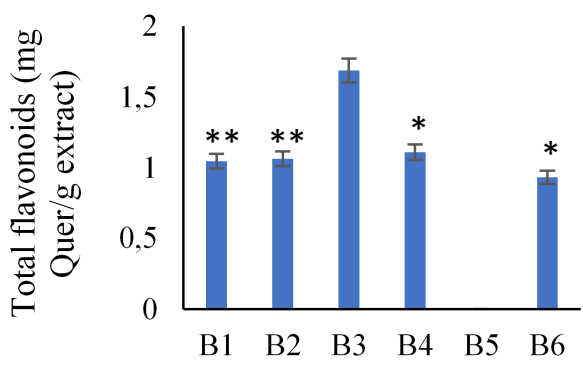

(F) Colchicine Pre-treatment

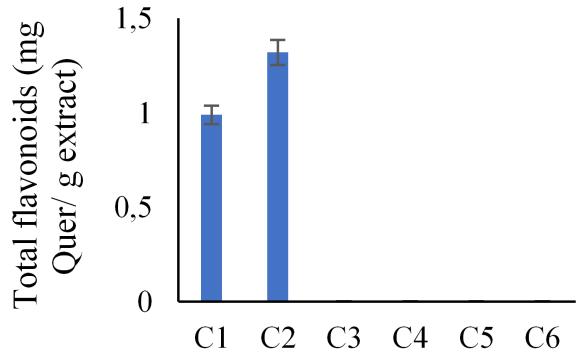

(G) Colchicine Pre-treatment

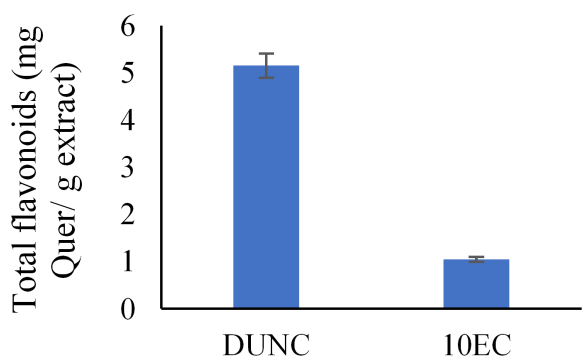

(H) Colchicine Pre-treatment

Figure 2 Total phenolic content expressed as gallic acid (GAE) equivalents (A-C) and flavonoid content expressed as quercetin (Quer) equivalents (E-G) of the methanol extracts in soybean pre-treated with 0.1 $(\mathrm{A} / \mathrm{E}), 0.5(\mathrm{~B} / \mathrm{F})$ and $1 \%(\mathrm{C} / \mathrm{G})$ colchicine, respectively. Values with asterisks $\left(^{*}\right)$ are not significantly different at $5 \%$ confidence level using t-test. 


\section{Conclusions}

The results demonstrated significant variations in terms of germination, seedling growth, phytochemicals and nucleic acids extracted from the samples. There were notable polynomial increases with the increase in the amount of colchicine and imbibitional duration applied. Increase in the concentration of colchicine proved detrimental to seed germination and seedling development. However, findings suggests that seeds could be exposed to minimum levels of colchicine with less imbibition period in order to increase the chance of producing better germination and seedling establishment for subsequent polyploidisation in soybean. Therefore, seed pre-treatment with colchicine should be further investigated as a good source of novel genetic variations required to confer stress tolerance in soybean.

\section{Acknowledgements}

The author would like to thank the Department of Research Development and Administration of the University of Limpopo for their support. Many thanks to Mr F. Nukeri, Mr B. Mdaka and Dr P.W. Mokwala for their valuable advice on phytochemical analysis. Colleagues in the Department of Biodiversity are also acknowledged.

\section{References}

[1] WH Jeong, K Harada, T Yamada, J Abe and K Kitamura. Establishment of new method for analysis of starch contents and varietal differences in soybean seeds. Breed Sci. 2010; 90, 160-3.

[2] A Manzoor, T Ahmad, MA Bashir, IA Hafiz and C Silvestric. Studies on colchicine induced chromosome doubling for enhancement of quality traits in ornamental plants. Plants. 2019; 8, 194.

[3] E Essel, IK Asante and E Laing. Effect of colchicine treatment on seed germination, plant growth and yield traits of cowpea (Vigna unguiculata (L.) Walp). Canadian J. Pure. Appl. Sci. 2015; 9, 3573-6.

[4] P Mangena, PW Mokwala and RV Nikolova. In vitro multiple shoot induction in soybean. Int. J. Agric. Biol. 2015; 17, 838-42.

[5] RF Boyer. Modern Experimental Biochemistry. $2^{\text {nd }}$ Edition. Benjamin Cummings, San-Francisco, USA, 1993, p. 379-85.

[6] AM Torres, T Mau-Lastovicka and R Rezaainyan. Total phenolics and high-performance liquid chromatography of phenolics in avocado. J. Agric. Food Chem. 1987; 35, 921-5.

[7] M Mingozzi, M Madeo and G Speranza. Effect of nitrogen starvation on the phenolic metabolism and antioxidant properties of yarrow. Food Chem. 2009; 114, 204-11.

[8] D Marinova, F Ribarova and M Atanassova. Total phenolics and total flavonoids in Bulgarian fruits and vegetables. J. Univ. Chem. Metall. 2005; 40, 255-60.

[9] J Zhishen, T Mengcheng and W Jianming. The determination of flavonoid contents in mulberry and their scavenging effects on superoxide radicals. Food Chem. 1999; 64, 555-9.

[10] T Masuko, A Minami, N Iwasali, T Majima, S Nishimura and YC Lee. Carbohydrates analysis by phenol-sulfuric acid method in microplate format. Ana Biochem. 2005; 339, 69-27.

[11] CF Barbas, DR Burton, JK Scott and GJ Silverman. Quantitation of DNA and RNA. Cold Spring Harbor Laboratory Press, Cold Spring Harbor, NY, USA, 2007.

[12] OG Bhusnure, VS Kuthar, SB Gholve, PP Jadhav, SG Zingade and PS Giram. Spectrophotometric method for quantitative estimation of DNA isolated from various parts of Catharanthus roseus Linn. J. Pharm. Res. 2017; 11, 625-8.

[13] ISTA-International Seed Testing Association. International rules for seed testing. Seed Sci. Tech. 1993; 29, 142-68.

[14] FJ Czabator. Germination value: An index combining speed and completeness of pine seed germination. For Sci. 1962; 8, 386-96.

[15] MA Kader. A comparison of seed germination calculation formulae and the associated interpretation of resulting data. J. Proc. Roy. Soc. New South Wales. 2005; 138, 65-75. 
[16] KC Gairola, AR Nautiyal and AK Dwivedi. Effect of temperature and germination media on seed germination of Jatropha curcas Linn. Adv. Bio-Res. 2011; 2, 66-71.

[17] AKMA Islam, N Anuar and Z Yaakob. Effect of genotypes and pre-sowing treatment on seed germination behaviour of Jatropha. Asian J. Plant Sci. 2009; 8, 433-9.

[18] M Nikolova, M Petrova, E Zayoza, A Vitkova and L Evstatieva. Comparative study of in vitro, ex vitro and in vivo grown plants of Arnica montana-polyphenols and free radical scavenging activity. Acta Bot. Croat. 2013; 72, 13-22.

[19] A Kafeel, ZI Khan, ZA Shah, M Irahim, I Mustafa and EE Valeem. Evaluation of available sugars in plant species indigenous to soone valley (Punjab) Pakistan. Pak. J. Bot. 2008; 40, 1877-83.

[20] JF Fannie and VJ Stadan. Gloriossa superba L. (Flame lily): micropropagation and in vitro production of colchicine. Medic. Arom. Plants. 1994; 6, 146-66.

[21] D Dhakhanamoorthy, R Selvaraj and A Chidambaram. Physicla and chemical mutagenics in Jatropha curcas L. to induce variability in seed germination, growth and yield traits. Rom. J. Plant Biol. 2010; 55, 113-25.

[22] S Pande and M Khetmalas. Biological effect of sodium azide and colchicine on seed germination and callus induction in Stevia rebaudiana. Asian J. Exp. Biol. Sci. 2012; 3, 93-8.

[23] W Widoretno. In vitro induction and characterization of tetraploid patchouli (Pogostemon cablin Benth.) plant. Plant Cell Tiss. Organ Cult. 2016; 125, 261-7.

[24] S Khalili, M Niazian, A Mustafa and M Norouzi. In vitro chromosome doubling of African daisy, Gerbera jamesonii Bolus cv. Mini Red. The Nucleus. 2020; 63, 59-65.

[25] OU Udensi and V Ontui. Determination by flow cytometry polyploidy inducing-capacity of colchicine in Cajanus cajan (L.) Mill sp. Parkistan J. Biol. Sci. 2013; 16, 630-5.

[26] S Amiri, SK Kazemitabaar, G Ranjbar and M Azadbakht. The effect of trifluralin and colchicine treatments on morphological characteristics of jimson weed (Datura stramonium L.). Trakia J. Sci. $2010 ; 8,47-61$.

[27] S Chandra, S Khan, B Avula, H Lata, MH Yang, MA Elsohly and IA Khan. Assessment of total phenolic and flavonoid content, antioxidant properties, and yield of aeroponically and conventionally grown leafy vegetables and fruit crops: A comparative study. Evi-Based Compl. Alter. Med. 2014; 253875, 1-9.

[28] EA Mogotlane, PW Mokwala and P Mangena. Comparative analysis of the chemical compositions of indigenous watermelon (Citrullus lanatus) seeds from two districts in Limpopo Province, South Africa. Afri J. Biotech. 2018; 17, 1001-6.

[29] RH Nieman and LL Poulsen. Spectrophotometric estimation of nucleic acid of plant leaves. Plant Physiol. 1963; 38, 31-5. 